\title{
Management of Physical Education Facilities and Infrastructure
}

\author{
Citra Dewi ${ }^{1 *}$, Desrio Windoro², Dwi Naomi Pura ${ }^{3}$ (D) \\ ${ }_{1,2,3}$ Faculty of Teacher Training and Education Dehasen Bengkulu University, Indonesia \\ e-mail: citravioleta04@unived.ac.id
}

\section{A R T I C L E I N F O}

Article history:

Received April 10, 2021

Revised April 12, 2021

Accepted May 12, 2021

Available online May 25, 2021

Kata Kunci:

Manajemen, Sarana,

Prasarana, Pendidikan

Jasmani

Keywords:

Management, Facilities

And infrastructures,

Physical Education

\begin{abstract}
A B S T R A K
Kurangnya sarana dan prasarana untuk pendidikan jasmani menyebabkan siswa kesulitan dalam berolahraga. Perhatian terhadap sarana dan prasarana Pendidikan Jasmani belum maksimal tercapai. Sebagian besar sekolah tidak memikirkan dan memperhatikan perencanaan, penyediaan atau pengadaan, penggunaan dan pemeliharaan sarana dan prasarana pendidikan jasmani.Penelitian ini bertujuan untuk menganalisis pengelolaan sarana dan prasarana pendidikan jasmani. Penelitian ini merupakan penelitian deskriptif dengan pendekatan kualitatif. Penelitian kualitatif bertujuan untuk memahami fenomena sosial dari perspektif partisipan. Partisipan ini adalah orang-orang yang diwawancarai, diamati, diminta untuk memberikan data, pendapat, pemikiran, dan persepsinya. Strategi penelitian bersifat fleksibel, menggunakan berbagai kombinasi teknik untuk memperoleh data yang valid melalui survei. Berdasarkan hasil penelitian diketahui bahwa melalui wawancara menunjukkan bahwa: pertama, perencanaan sarana pembelajaran pendidikan jasmani dilakukan berdasarkan analisis kebutuhan dan penentuan skala prioritas kegiatan yang akan dilaksanakan, sesuai dengan ketersediaan. dana dan tingkat kepentingannya. Kedua, penyediaan fasilitas pembelajaran dilakukan dengan mengutamakan aspek fungsi (utility) yang mengacu pada kegunaan fasilitas tersebut. Terkait dengan kebutuhan nyata sekolah. Ketiga, pemanfaatan fasilitas pembelajaran pendidikan jasmani selain untuk kegiatan akademik berupa belajar mengajar di kelas, juga digunakan untuk menunjang terselenggaranya berbagai kegiatan sekolah. Keempat, penyimpanan fasilitas pembelajaran dikoordinasikan oleh personel yang ditunjuk. Pengangkatan personel dengan persyaratan yang disepakati.
\end{abstract}

\section{A B S T R A C T}

Lack of facilities and infrastructure for physical education causes students to have difficulty exercising. Attention to physical education facilities and infrastructure have not been maximally achieved. Most schools do not consider planning, providing or procuring, using, and maintaining physical education facilities and infrastructure. This study aims to analyze the management of physical education facilities and infrastructure. This research is descriptive research with a qualitative approach. Qualitative research aims to understand social phenomena from the participant's perspective. These participants are interviewed, observed, asked to provide data, opinions, thoughts, and perceptions. The research strategy is flexible, using various combinations of techniques to obtain valid data through surveys. Based on the study results, it was found that interviews showed that: first, the planning of physical education learning facilities was carried out based on needs analysis and determining the priority scale of activities to be carried out, according to availability: funds and their importance. Second, the provision of learning facilities is carried out by prioritizing function (utility), which refers to the facility's usefulness - related to the real needs of the school. Third, the use of physical education learning facilities and academic activities in teaching and learning in the classroom is also used to support the implementation of various school activities. Fourth, the storage of learning facilities is coordinated by designated personnel — appointment of personnel on agreed terms.

This is an open access article under the CC BY-SA license.

Copyright (C) 2021 by Author. Published by Universitas Pendidikan Ganesha.

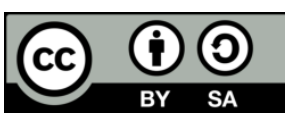

\section{INTRODUCTION}

The scope of Physical Education subjects includes aspects of sports games, development activities, gymnastics activities, rhythmic activities, and health (Almusawi et al., 2021; Phelps et al., 2021; Setiawan et al., 2020; Womsiwor et al., 2020). The quality of the success and success of Physical Education learning is strongly influenced by elements including teachers as the main element, students, curriculum, goals, methods, facilities and infrastructure, assessment, management, and classroom atmosphere (Gustiana \& Puspita, 2020; Nur \& Malik, 2021; Wang et al., 2021; Zhan et al., 2021). The success of the teaching and learning process of Physical Education is determined by several factors, namely internal factors and external factors (Dupri et al., 2020; Rokhayati et al., 2016; Rustiana, 2011; Wirasasmita \& Hendriawan, 2020). Internal factors are teachers and 
physical education facilities and infrastructure as a tool to carry out teaching and learning activities in schools. External factors include family factors, environmental factors, and community factors. Facilities and infrastructure are some of the elements supporting the success of Physical Education (Gillani, 2021; Hidayat, 2017; Wiranto \& Slameto, 2021). Moreover, these subjects require a lot of facilities and infrastructure to support the achievement of effective learning. Sports infrastructure is something that supports the implementation of a physical education learning process. In physical education learning, infrastructure is defined as something that facilitates or speeds up the process. One characteristic of physical infrastructure is that it is relatively permanent or difficult to move (Andli Marta \& Oktarifaldi, 2020; Ningsih et al., 2018).

The current problem is the lack of facilities and infrastructure for physical education (Basuki, 2017; Widiastuti, 2019; Zainudin et al., 2019). Based on observations made in several public elementary schools in Muara Sahung District, Kaur Regency, such as SD Negeri 96 Kaur, SD Negeri 77 Kaur, and SD Negeri 125, it is known that attention to physical education facilities and infrastructure have not been maximally achieved. Most schools do not consider planning, providing or procuring, using, and maintaining physical education facilities and infrastructure. In addition to adequate facilities and infrastructure, the management of facilities and infrastructure also needs attention. Because facilities and infrastructure need to be cared for and managed properly to be durable and support learning sustainably. Therefore, the importance of the management of physical education facilities and infrastructure is closely related to the use of facilities and infrastructure to achieve learning to support the achievement of quality education. This happened not only in one school but in more than half of the primary schools in the class. So the condition of sports facilities and infrastructure is almost the same. The problem that was later encountered was the lack of optimal knowledge conveyed to students because they could only teach a sport through game modification. This is because when learning takes place, the facilities and infrastructure owned by the school are damaged, and there has been no updating. This problem is also an example of the harmful impact of sports management in primary schools in the field, which was found from field observations.

Meanwhile, the management of facilities and infrastructure is one of the factors that impact learning to achieve optimal learning outcomes (Black et al., 2019; Gillani, 2021). Management is an activity to move a group of people and direct all facilities to achieve specific goals. In this case, the management of Physical Education facilities and infrastructure is very beneficial for teachers and students so that learning can run smoothly and learning objectives can be adequately achieved (Beusker et al., 2012; Lau et al., 2021). Because there are still many elementary schools, educational facilities and infrastructure have not been appropriately managed, such as there is no particular room to store infrastructure properly, most elementary school teachers have not been equipped with the management of sports facilities and infrastructure. Because they are not equipped during their lectures, with the existence of infrastructure, good advice management relations will impact the learning process (Widiastuti, 2019).

The lack of awareness of proper maintenance procedures for sports facilities and infrastructure by managers of facilities and infrastructure is also very influential in managing physical education facilities and infrastructure in schools (Seifried et al., 2021; Vala et al., 2021). For example, in the use of the ball during learning, when the wet ball is exposed to water, the ball is immediately put into the sports equipment storage warehouse without wiping or cleaning the wet and dirty ball first. Of course, this has an impact on the durability of the ball if students always do this when returning all types of equipment used. After using all types of sports equipment, it is best to clean it before storing it in storage. The benefits of physical education facilities and infrastructure to support the learning process are; (1) Can spur the growth and development of students because students behave, think, and move. In this case, the facilities and infrastructure can motivate students to behave and do physical activity. (2) Movement can be more effortless or challenging (Kumar, Manoli, Hodgkinson, \& Hodgkinson, 2018; Shrestha et al., 2019). With facilities and infrastructure, it can facilitate complicated movements. For example, rocking bolsters are more accessible to assist with jumping chests than without using jumping crates. On the other hand, hooks complicate easy movements. For example: generally doing initial movements without tools is more accessible than using tools, (3) Can be used as a measure of success, and (4) Attracts students' attention.

Building physical education facilities and infrastructure requires a relatively expensive cost. Therefore, its maintenance also requires much money. The use of existing physical education facilities and infrastructure must be maintained to be used for a long time. For this reason, it is necessary to know the nature of managing physical education facilities and infrastructure, including determining needs, procurement process, use (use of infrastructure can be divided into 2; consumables and non-consumable goods), recording and management, which includes (book inventory, purchase books, books, and goods cards), as well as accountability for the use of school inventory items. Thus the remaining budget can be allocated for sports development programs. 


\section{METHOD}

The location of this research coincides in elementary schools in the Muara Sahung sub-district of the Kaur district, but this research only focuses on elementary schools in Muara Sahung sub-district of the Kaur district. The following is a description of the Kaur district. To obtain the information needed in solving research problems, this research will be carried out in each school, especially the Public Elementary Schools in Kaur District, which consists of 8 elementary schools. The names of these elementary schools are:

Table 1. List of Public Elementary School Names in Kaur District

\begin{tabular}{llll}
\hline No. & School Name & No. & School Name \\
\hline 1 & SDN 110 Kaur & 5 & SDN 129 Kaur \\
2 & SDN 122 Kaur & 6 & SDN 77 Kaur \\
3 & SDN 125 Kaur & 7 & SDN 96 Kaur \\
4 & SDN 128 Kaur & 8 & SDN 106 Kaur \\
\hline
\end{tabular}

The research form used in this research is descriptive qualitative approach. Qualitative research is aimed at understanding social phenomena from the perspective of the participants. These participants are people who are interviewed, observed, asked to provide data, opinions, thoughts, and perceptions. The research strategy is flexible, using various combinations of techniques to obtain valid data through surveillance (Sugiyono, 2017). The survey method is a study that is carried out by collecting relatively limited data from a relatively large number of cases (Sugiyono, 2017). Basically a survey is useful for knowing what is there without questioning why it is there. This research is a survey research that solely reveals the symptoms that occur as they are without giving or intervention by the researcher, so this research can be categorized as a descriptive study. This research is descriptive qualitative in nature, but because it is symbolized by numbers so that the data collected in this study is quantitative. This type of qualitative descriptive research used in this study is intended to obtain information about the Management of Facilities and Infrastructure for Physical Education in Elementary Schools in Muara Sahung District, Kaur Regency. Data Collection Techniques When viewed from the data collection techniques can be done by interview (interview), observation (observation), and documents. In qualitative research, the main instrument is the researcher himself, but then after the research focus becomes clear, a simple research instrument will be developed where the research instruments developed in this study are interviews, observation, documentation.

\section{RESULT AND DISCUSSION}

Researchers obtained research data through observation sheets, interviews, and documentation. This technique is data collection which is done by giving written questions to the respondent. Researchers retrieve data assisted by the physical education teacher concerned. The physical education teacher is concerned with the data source by showing the location of the physical education facilities and infrastructure. The data taken by the researcher includes the existence, number, ownership status, condition of physical education facilities and infrastructure, along with other information that supports the data. Identification of the existence, ownership status, management, and conditions aims to determine the completeness of physical education facilities and infrastructure that support learning effectiveness. The greater the number of physical education facilities and infrastructure, the more support these tools are for physical education learning.

This study used the interview method, and interviews were conducted with the principal, vice-principal of the curriculum, and physical education teachers. Planning for educational infrastructure in schools should refer to the Republic of Indonesia Government Regulation Number 19 of 2005 concerning National Education Standards article 42. Learning facilities that academic units must own are described as follows: "Every educational unit is required to have facilities which include furniture, educational equipment, media. education, books and other learning resources, consumables, and other equipment needed to support an orderly and sustainable learning process. " In learning, physical education is in dire need of means and facilities to support the success of learning ignition so that an active, creative, effective, and fun learning process can be created for students. To achieve this, the learning facilities in each academic unit must meet the minimum criteria set out in the standard of facilities and infrastructure.

However, the condition of the facilities and infrastructure in your district, especially at SDN 110 Kaur, SDN 122 Kaur, SDN 125 Kaur, SDN 128 Kaur, SDN 129 Kaur, SDN 77 Kaur, SDN 96 Kaur, and SDN 106 Kaur, have Inadequate planning due to limited facilities so that many learning methods use modifications so that learning acquisition is slightly less achieved. From the school side, they do not pay much attention to the condition of the facilities, so that physical education teachers use the minimum learning equipment. In interviews 
conducted with several principals of Kaur district schools, it was found that the steps for planning learning facilities were not initiated from an analysis of the educational needs of a community but based on the proposal for the procurement of school equipment submitted by school management and physical education teachers because the school had understood the educational needs of the community. It is based on the education unitlevel curriculum that the school has developed. The KTSP was developed based on an analysis of the education needs of the Kaur district community and its surroundings while still paying attention to the ability of the school to equip learning facilities that support the implementation of education in the school. The next step that the school did not take was: surveying all school units to compile a master plan for a certain period. From observations during the study, the school simplified this step by accommodating all the equipment procurement suggestions submitted by the school management. When confirmed to the waka for infrastructure, this step was taken in the context of efficiency, considering that primary schools in the Kaur district do not yet have large school units. Regarding educational programs, the school is very concerned about the organization of the school curriculum, teaching methods, and the necessary teaching media. About available funds, there are several sources of funds usually owned by primary schools in the Kaur district that have government funding sources in the form of school operational assistance and routine funds.

In providing facilities to meet needs by developing education in elementary schools in the Kaur district and replacing damaged or lost goods, the procurement of learning facilities is carried out carefully so that all procurement of these tools can be by needs. The step of procuring learning facilities at the Kaur Regency Elementary School was preceded by forming a procurement team. Next, the team works by considering the needs of facilities and their suitability with the school's budget. Next, determine the final procurement plan. The steps in the SOP for the procurement of learning facilities are as follows: (a) accommodate all proposals for the procurement of school equipment submitted by each work unit and take an inventory of the shortage of school equipment. (b) prepare a plan for school equipment needs for a certain period, for example, for one semester or one academic year, (c) combine the needs plan that has been prepared with previously available equipment, (d) integrate the needs plan with the available school funds or budget (Bunds et al., 2018; Kumar, Manoli, Hodgkinson, \& Downward, 2018). If the available funds are not sufficient to meet these needs, it is necessary to select all the equipment needs planned by considering the urgency of each piece of equipment needed. All urgent equipment is registered immediately, (e) combines the plan (list) of urgent equipment needs with available funds or budget if it still exceeds the available budget, needs to be re-selection by making a priority scale, (f) determining the end of the procurement plan (Chang et al., 2020; Marijon et al., 2015).

The arrangement and utilization of physical education learning facilities in elementary schools in Kaur Regency have been carried out optimally and consider the principles of effective and efficient management of learning facilities. The utilization of learning facilities in elementary schools in Kaur Regency is carried out by considering differentiating tools divided into two categories: 1) Tools that are directly used in the teaching and learning process. For example, learning tools, teaching aids, educational media. In this case, in general, when the facilities and infrastructure and physical education teachers are responsible for managing learning facilities and infrastructure in the form of educational tools and media (Halonen et al., 2015; Mulyana, 2017). However, teachers and students who are directly involved in the use of tools and media during learning activities have their respective responsibilities for using these learning tools (Irawan, 2017; Juditya et al., 2020). 2) Tools that are not directly involved in the teaching and learning process. For example, teacher's desk, administrative office furniture. Waka of facilities and infrastructure is responsible for regulating the use of these facilities, which has been carried out since before the tools were used. These arrangements include: 1) Giving identity in the form of inventory with a specific code for certain types. 2) Record the tools into the inventory list book. Furthermore, the use of tools is carried out by considering four factors, namely: (1) the number of tools for each type, (2) the number of classes, (3) the number of students in each class, (4) the number of rooms or places in the school.

Physical education learning facilities used in sports learning activities are helpful for teachers in providing educational services and valuable for students in understanding the message conveyed (Asriansyah, 2018; Nur \& Malik, 2021). From observations on the implementation of physical education learning activities in elementary schools in the Kaur district, the use of learning facilities in the form of sports equipment in the form of books and tools such as shooting balls for exercise equipment has an impact on the creation of active learning. This can be understood considering that in learning, students involve more physical activity than other learning. All school residents also use physical education learning facilities in elementary schools in Kaur Regency to implement school activities even though they have limited tools. Many types of equipment have changed their functions into modified means to achieve learning despite the results obtained. Achievement is not optimal.

Storage of learning facilities in elementary schools in Kaur Regency is intended so that existing English learning facilities are well maintained, not easily damaged, and can be used continuously. In the storage aspect, pay attention to the dimensions of the following standard maintenance operational procedures: 1 . Objectives and benefits of standard facility maintenance operational procedures: (1) Provide direction, information on the maintenance of school facilities and infrastructure, (2) provide space for policymaking to maintain facilities and 
infrastructure. 2. Distribution/target of facility maintenance standard operating procedures, which include; (1) Principal as a person in charge, (2) Deputy Principal, (3) Teachers and homeroom teachers, (4) Students and parents/guardians, (5) Regency/Municipal Education Supervisor, (6) Regency/Municipal Education Office City City, (7) Other Stake Holders. 3. The procedures and mechanisms for maintaining facilities are as follows: (1) Every item and equipment that enters the school must first be included in the inventory list, (2) Existing school goods and facilities must be maintained periodically and charged accordingly. Budget, (3) Maintenance includes: meanwhile, light maintenance can be carried out by school technicians. Heavy maintenance may involve professional technicians, (4) maintenance is carried out on facilities and infrastructure by considering the economic value, (5) maintenance procedures are as follows: a) Deputy Principal receives reports from teachers, homeroom teachers, students, or education staff regarding facility damage they encounter, b) The facility representative checks the report and takes notes and determines the type of damage (severe or minor). Waka means giving an oral/or written report to the principal and asking for directions, the principal providing a solution or delegating the means to take appropriate steps when the facility coordinates with the school janitor or a third party After the maintenance and maintenance is complete, the vice principal gives a report to the principal accompanied by proof of expenditure. One of the main obstacles in maintaining physical education learning facilities in primary schools in the Kaur district is the unavailability of storage space. Meanwhile, it is solved by using other available space. One way of storing and maintaining learning facilities that can be done is by providing vertical furniture that can save space. This is appropriate for small schools such as elementary schools in Kaur District.

\section{CONCLUSION}

The results showed that: First, planning for physical education learning facilities was carried out based on a needs analysis and determining the priority scale of activities to be carried out, by the availability of funds and the level of importance. Second, the provision of learning facilities is carried out by prioritizing aspects of function (utility), which refer to the usefulness of these facilities-related to the real needs of schools. Third, the use of physical education learning facilities and academic activities in teaching and learning in class is also used to support the implementation of various school activities. Fourth, the storage of learning facilities is coordinated by designated personnel-appointment of personnel with agreed conditions.

\section{REFERENCES}

Almusawi, H. A., Durugbo, C. M., \& Bugawa, A. M. (2021). Innovation in physical education: Teachers' perspectives on readiness for wearable technology integration. Computers \& Education, 167. https://doi.org/10.1016/j.compedu.2021.104185.

Andli Marta, I., \& Oktarifaldi. (2020). Koordinasi Mata-Kaki Dan Kelincahan Terhadap Kemampuan Dribbling Sepakbola. Pendidikan Jasmani Dan Olahraga, 4(3), 1-14. https://doi.org/10.31539/jpjo.v4i1.1201.

Asriansyah, A. (2018). Pengembangan Permainan Tradisional untuk Melestarikan Budaya Bangsa melalui Pembelajaran Pendidikan Jasmani Sekolah Dasar. Jurnal Pendidikan Jasmani Dan Olahraga, 3(1). https://doi.org/10.17509/jpjo.v3i1.10597.

Basuki, S. (2017). Partisipasi Mahasiswa Dalam Kegiatan Olahraga Dan Sarana Prasarana Pendukung Pada Universitas Lambung Mangkurat. Multilateral: Jurnal Pendidikan Jasmani Dan Olahraga, 16(1). https://doi.org/10.20527/multilateral.v16i1.3659.

Beusker, E., Stoy, C., \& Pollalis, S. N. (2012). Estimation model and benchmarks for heating energy consumption of schools and sport facilities in Germany. Building and Environment, 49. https://doi.org/10.1016/j.buildenv.2011.08.006.

Black, N., Johnston, D. W., Propper, C., \& Shields, M. A. (2019). The effect of school sports facilities on physical activity, health and socioeconomic status in adulthood. Social Science \& Medicine, 2020. https://doi.org/10.1016/j.socscimed.2018.10.025.

Bunds, K. S., Kanters, M. A., Venditti, R. A., Rajagopalan, N., \& Casper, J. M. (2018). Organized youth sports and commuting behavior: The environmental impact of decentralized community sport facilities. Transportation Research Part D: Transport and Environment, 65. https://doi.org/10.1016/j.trd.2018.08.017.

Chang, M., Bang, H., Kim, S., \& Nam-Speers, J. (2020). Do sports help students stay away from misbehavior, suspension, or dropout? Studies in Educational Evaluation, 70. https://doi.org/10.1016/j.stueduc.2021.101066.

Dupri, D., Candra, O., Candra, A., \& Suryani, D. A. (2020). The Implementation of Problem Based Learning 
Model in Improving Cooperation and Learning Outcomes in Physical Education. Jurnal Pendidikan Jasmani Dan Olahraga, 5(1). https://doi.org/10.17509/jpjo.v5i1.22531.

Gillani, A. A. (2021). The association between presence of sanitation facilities and school enrolment in Pakistan. World Development Perspectives, 21. https://doi.org/10.1016/j.wdp.2021.100289.

Gustiana, A. D., \& Puspita, R. D. (2020). The Effect of Educative Games on the Physical Fitness of Kindergarten Children. Jurnal Pendidikan Jasmani Dan Olahraga, 5(2). https://doi.org/10.17509/jpjo.v5i2.24518.

Halonen, J. I., Stenholm, S., Beta, Kivimaki, M., \& Pentti, J. (2015). Is change in availability of sports facilities associated with change in physical activity? A prospective cohort study. Preventive Medicine, 73. https://doi.org/10.1016/j.ypmed.2015.01.012.

Hidayat, T. (2017). Studi Komparatif Dua Fitnes Center Terbesar di Kota Bandung dalam Hal Kualitas Pelayanan dan Sarana-prasarana serta Pengaruhnya terhadap Minat Pengunjung. Jurnal Pendidikan Jasmani Dan Olahraga, 2(1). https://doi.org/10.17509/jpjo.v2i1.6396.

Irawan, D. (2017). Pengembangan Media Berabasis Adobe Flash Player Pencegahan, Pertolongan, Dan Perawatan Cedera Olahraga Bagi Guru Pendidikan Jasmani Sekolah Menengah Pertama (SMP). Jurnal Pendidikan Jasmani Dan Olahraga, 2(2). https://doi.org/10.17509/jpjo.v2i2.8172.

Juditya, S., Suherman, A., Ma'mun, A., \& Rusdiana, A. (2020). The Basic Movement Skill Test Instrument of Ball Games for Students Aged 13-15 Years. Jurnal Pendidikan Jasmani Dan Olahraga, 5(1). https://doi.org/10.17509/jpjo.v5i1.21447.

Kasriman, K. (2017). Motivasi Masyarakat Melakukan Olahraga Rekreasi melalui Program Car Free Day di Jakarta. Jurnal Pendidikan Jasmani Dan Olahraga, 2(2). https://doi.org/10.17509/jpjo.v2i2.8183.

Kumar, H., Manoli, A. E., Hodgkinson, I. R., \& Downward, P. (2018). Sport participation: From policy, through facilities, to users' health, well-being, and social capital. Sport Management Review, 21(5). https://doi.org/10.1016/j.smr.2018.01.002.

Kumar, H., Manoli, A. E., Hodgkinson, I. R., \& Hodgkinson, I. R. (2018). Sport participation: From policy, through facilities, to users' health, well-being, and social capital. Sport Management Review, 21(5). hhttps://doi.org/10.1016/j.smr.2018.01.002.

Lau, E., Hou, H. (Cynthia), Lai, J. H. K., Edwards, D., \& Chileshe, N. (2021). User-centric analytic approach to evaluate the performance of sports facilities: A study of swimming pools. Journal of Building Engineering, 44. https://doi.org/10.1016/j.jobe.2021.102951.

Marijon, E., Beta, Bougouin, W., Karam, N., \& Beganton, F. (2015). Survival from sports-related sudden cardiac arrest: In sports facilities versus outside of sports facilities. American Heart Journal, 170(2). https://doi.org/10.1016/j.ahj.2015.03.022.

Mulyana, N. (2017). Hubungan Gaya Kepemimpinan Guru dalam Meningkatkan Motivasi Belajar Penjas pada Siswa Sekolah Dasar. Jurnal Pendidikan Jasmani Dan Olahraga, 2(1). https://doi.org/10.17509/jpjo.v2i1.6399.

Ningsih, Arif Hidayat, \& Kusairi, S. (2018). Penerapan Problem Based Learning Untuk Meningkatkan Kemampuan Berpikir Kritis Dan Hasil Belajar Siswa Kelas III. Jurnal Pendidikan, 3(12), 1587-1593.

Nur, L., \& Malik, A. A. (2021). Basketball Skill Achievements: Comparison between Technical Approach and Tactical Approach based on Physical Fitness Level. Jurnal Pendidikan Jasmani Dan Olahraga, 6(2). https://doi.org/10.17509/jpjo.v6i1.31610.

Phelps, A., Colburn, J., Hodges, M., \& Hodges, M. (2021). A qualitative exploration of technology use among preservice physical education teachers in a secondary methods course. Teaching and Teacher Education, 105. https://doi.org/10.1016/j.tate.2021.103400.

Rokhayati, A., Nur, L., Gandana, G., \& Elan, E. (2016). Implementasi Pendekatan Taktis dalam Pembelajaran Pendidikan Jasmani Terhadap Motivasi, Kebugaran Jasmani dan Kemampuan Motorik. Jurnal Pendidikan Jasmani Dan Olahraga, 1(2). https://doi.org/10.17509/jpjo.v1i2.5664.

Rustiana, E. R. (2011). Efek Psikologis dari Pendidikan Jasmani ditinjau dari Teori Neurosains dan Teori Kognitif Sosial. Media Ilmu Keolahragaan Indonesia, 1(2). https://doi.org/10.15294/miki.v1i2.2035.

Seifried, C., Agyemang, K. J. A., Walker, N., \& Soebbing, B. (2021). Sport management and business schools: A growing partnership in a changing higher education environment. The International Journal of Management Education, 19(3). https://doi.org/10.1016/j.ijme.2021.100529.

Setiawan, A., Kharisma, Y., \& Yohan, S. (2020). The Effect of Direct Instruction Learning Model on The Underpass Learning Outcome in Volleyball. Jurnal Pendidikan Jasmani Dan Olahraga, 5(2). https://doi.org/10.17509/jpjo.v5i2.23487.

Shrestha, S., Kestens, Y., Thomas, F., Aarbaoui, T. El, \& Chaix, B. (2019). Spatial access to sport facilities from the multiple places visited and sport practice: Assessing and correcting biases related to selective daily mobility. Social Science \& Medicine, 236. https://doi.org/10.1016/j.socscimed.2019.112406.

Sugiyono. (2017). Metode Penelitian Kuantitatif, Kualitatif, dan R\&D. Alfabeta. 
Vala, R., Valova, M., Drazdilova, P., Krömer, P., \& Platos, J. (2021). Behaviour associated with the presence of a school sports ground: Visual information for policy makers. Children and Youth Services Review, 128. https://doi.org/10.1016/j.childyouth.2021.106150.

Wang, Y., Muthu, B., \& Sivaparthipan, C. B. (2021). Internet of things driven physical activity recognition system for physical education. Microprocessors and Microsystems, 81. https://doi.org/10.1016/j.micpro.2020.103723.

Widiastuti, W. (2019). Mengatasi Keterbatasan Sarana Prasarana Pada Pembelajaran Pendidikan Jasmani [Overcoming Facilities Limitations Affecting Physical Education Learning Activities]. Polyglot: Jurnal Ilmiah, 15(1). https://doi.org/10.19166/pji.v15i1.1091.

Wiranto, R., \& Slameto, S. (2021). Alumni satisfaction in terms of classroom infrastructure, lecturer professionalism, and curriculum. Heliyon, 7(6). https://doi.org/10.1016/j.heliyon.2021.e06679.

Wirasasmita, \& Hendriawan. (2020). Analisis Efisiensi Kinerja Pendidik terhadap Hasil Pembelajaran Pendidikan Jasmani pada Siswa Sekolah. Mimbar Pendidikan, 5(1), 75-90.

Womsiwor, D., Adiputra, N., Bakta, I. M., Purba, A., Jawi, I. M., Suyasa, I. K., \& Fitria, N. (2020). A Predominant Physical Component Profile of Persipura Junior Football Athletes. Jurnal Pendidikan Jasmani Dan Olahraga, 5(1). https://doi.org/10.17509/jpjo.v5i1.23792.

Zainudin, N. I., Athar, A., \& Kahri, M. (2019). Analisis Komponen Kebugaran Jasmani Peserta Didik Sekolah Dasar Negeri Di Lihat Dari Sarana Dan Prasarana Pendidikan Jasmani Kelas V Usia 10 - 12 Tahun Kota Banjarbaru. Multilateral: Jurnal Pendidikan Jasmani Dan Olahraga, 18(1). https://doi.org/10.20527/multilateral.v18i1.6570.

Zhan, X., Clark, C. C. T., Bao, R., \& Duncan, M. (2021). Association between physical education classes and physical activity among 187,386 adolescents aged 13-17 years from 50 low- and middle-income countries. Jornal de Pediatria, 5. https://doi.org/10.1016/j.jped.2020.11.009. 